\title{
Perceptions of Teachers about Information and Communication Technologies (ICT): A Study of Metaphor Analysis
}

\author{
Gokhan Bas \\ Nigde Omer Halisdemir University, Turkey
}

\begin{abstract}
This study aimed to examine metaphorical conceptions of high school teachers $(n=224)$ in Turkey about information and communication technologies (ICT). Phenomenological research design was adopted to examine teachers' perceptions about ICT in the current study. The results of the study showed that teachers produced a total of 46 valid metaphors clustered under five (knowledge source, guide, reform, plant, and problem) main conceptual categories. Although teachers produced a large number of metaphors, there was no significant differences between their metaphorical conceptions about ICT with regard to gender.
\end{abstract}

Keywords: Information and communication technologies; Metaphor analysis; Phenomenological research; Teacher perceptions.

\section{Introduction}

Technology is quickly entering into people's daily lives; at the same time, making their lives easier in many ways as well (Marvin, 1997). Technology has occupied an important place in many areas of life in the globalized world, as well as it has become a driving force in the progression of social life (Wilson, 2003). Technology not only has a driving force in the progression of social life, but it also has a dynamic structure with important effects on education systems (Watson, 2001). With the introduction of computer in education, which is one of the most important technologies of the twenty-first century, it seems possible to say that computer technology has a considerable place in today's schools (Lai \& Pratt, 2004). Recently, with the frequent use of computers in education, the resulting situation forces countries to integrate information and communication technologies (ICT) into their education systems effectively (Tondeur, van Keer, van Braak, \& Valcke, 2008).

While information and communication technologies (ICT) are a combination of information technologies (IT) and communication technologies (CT), they include software and applications related to computer and internet technologies (Tezci, 2010). ICT, which has a very important place in the education systems of contemporary societies, has been used extensively in teaching and learning process in schools of many countries lately. Today, while there is a lot of evidence for the effectiveness of ICT in teaching and learning process in schools (Altun, 2002), Turkey has taken significant and important steps for the use of these technologies in its education system in recent years. As contemporary societies believe that ICT is a potential tool for change and reform in teaching and learning process (Papanastasiu \& Angeli, 2008), Turkey as a developing country could not stay away from this potential of change and reform (Altun, 2002). Turkey has 
taken many steps in order to closely monitor the changes and developments in the effective use of ICT in schools (Light, 2009). In this sense, the Ministry of National Education (MoNE) of Turkey has invested a lot on the integration of ICT to overcome the problems and make renovations in education (Tezci, 2010). The main purpose of these investments in the integration of ICT in education by the MoNE was to improve the quality of teaching and learning process in the classroom (Goktas, Gedik, \& Baydas, 2013). Although ICT has a very strong effect in education, it can be said that the main strong impact of it is on the improvement of the quality of teaching and learning process (Cavas, Cavas, Karaoglan, \& Kisla, 2009). Also, the MoNE is making significant efforts in order to integrate ICT in teaching and learning process efficiently, and is making investments with big budgets in this direction (Dundar \& Akcayir, 2014).

Efforts towards the integration of technology in education in the Turkish Education System (TES) started nearly twenty-five years ago with "Computer Assisted Education Project" (CAEP) (Yilmaz, 2011). Another big project in the TES was titled as "Catching the Era in Education 2000" (CEE 2000). While the main purpose of CEE 2000 was to integrate ICT in the education system itself (Yilmaz, 2011), many tools as computers, projectors, printers, overhead projectors was distributed to schools within the scope of this project (Somyurek, Atasoy, \& Ozdemir, 2009). The latest project, which is still being implemented and including technology integration in the TES is "Increasing the Opportunities and Improving Technology Movement", also called shortly as F@tih project (Kurt, Kuzu, Dursun, Gullepinar, \& Gultekin, 2013). F@tih project, which has been launched in 2010 by the MoNE, is planned to be completed in four years and 1.5 billion Turkish Liras (approximately 750 million Dollars) to be spent on in this direction (Dundar \& Akcayir, 2014). Interactive white boards (IWB), tablet PCs (TPC), projectors, and printers are being distributed in schools within the scope of F@tih project (Ciftci, Taskaya, \& Alemdar, 2013), which aims to make each student acquire the skills of the twenty-first century and establish teachers sustain effective teaching and learning process in the classroom (Uluyol, 2013). When the project is completed, all the primary, middle, and high schools in the TES are expected to be sustained with IWBs, as well as teachers are expected to be provided with TPC (Ciftci, Taskaya, \& Alemdar, 2013).

The integration of ICT in education is an issue that has quite a lot of important advantages in the related literature (Livingstone, 2012). However, common experience that many countries demonstrate reveals that integration of ICT in teaching and learning process does not mean setting it by purchasing only hardware and software (Somyurek, Atasoy, \& Ozdemir, 2009). As there are many various factors in the effective integration of ICT in teaching and learning process (Bingimlas, 2009; Pelgrum, 2001; Sang, Valcke, van Braak, \& Tondeur, 2010), teachers' perceptions and attitudes towards ICT can be said to be the leading factors (Selwyn, 1999). Indeed, teachers' perceptions and attitudes in regard of the integration of ICT in teaching and learning process are quite significant in the use of these technologies in educational processes (Huang \& Liaw, 2005). Teachers' positive perceptions and attitudes towards the use of ICT are considered as a very important factor in the effective integration of ICT in teaching and learning process (Loveless, 2003). When looked from the reversed side, teachers' negative perceptions and attitudes towards the use of ICT are considered as an important obstacle in the integration of these technologies in teaching and learning process (Teo, 2008). In this sense, teachers' perceptions in terms of the effective integration of ICT in teaching and learning process are thought to affect the use of these technologies in the classroom significantly (Blurton, 1999). Yet, technology has not an educational value by itself. Its educational value arises when teachers use it in the process of teaching and learning efficiently (Tezci, 2010). In other words, teachers' ICT-related perceptions and beliefs are seen more important than the availability of these technologies in schools (Inan \& Lowther, 2010). Because, investing solely on hardware and 
software may not provide effective use of ICT in teaching and learning process in the classroom (Somyurek, Atasoy, \& Ozdemir, 2009). Considering the fact that teachers have an important role in teaching and learning process (Borich, 2014; Kauchak \& Eggen, 2012), their positive or negative perceptions in regard of the effective integration of ICT in teaching and learning process can be said to affect the use of these technologies in the classroom significantly (Tezci, 2010). According to Davies and Bromber (2001), perceptions of teachers towards these technologies are seen to be quite important in the successful integration of ICT in teaching and learning process. Ultimately, teachers have a critical role in integrating ICT effectively into teaching and learning process, and the perceptions these teachers in regard of the use of these technologies can be said to be very crucial. It should never be overlooked that investments solely on these technologies would not resort an effective teaching and learning process by ignoring the perceptions of teachers about ICT (Tondeur, Valcke, \& van Braak, 2008). Therefore, the barriers in front of an effective integration of ICT into teaching and learning process can be understood by examining teachers' perceptions closely.

When the relevant literature is reviewed, it is observed that there are many studies examining teachers' integration of ICT processes into education both at national and international scope. As these studies are examined, it is seen that there are many factors effective in the integration of ICT by teachers (Goktas, Yildirim, \& Yildirim, 2009; Sang, Valcke, van Braak, \& Tondeur, 2010). Among these factors, it is understood that attitudes, perceptions, and beliefs of teachers towards ICT have quite significant effects (Niederhauser \& Stoddart, 2001). Hence, it can be said that teachers' attitudes, perceptions, and beliefs may affect the process of effective ICT integration into teaching and learning process.

Many methods of research for determining the perceptions and beliefs of teachers about ICT are available (Fraenkel \& Wallen, 2009); however, metaphors, which are considered the most powerful tools for configuring, directing, and controlling ideas about the functioning of something, are thought to be very effective in explaining such states (Saban, Kocbeker, \& Saban, 2007). Indeed, metaphors reflect the belief of an individual, and beliefs focus on the individual's perceptions (Kalra \& Baveja, 2012). The concept of metaphor, which was accepted as rhetoric and held in the context of literature and linguistics studies initially, has become established in the center of interdisciplinary research with the effect of "cognitive metaphor theory" (Alparslan, 2007). The cognitive metaphor theory, as cognitive structures shaping the world and reality perceptions of the human, has been first proposed by Lakoff and Johnson (1980) in their seminal and pioneering work. Metaphors have been described in many ways by many researchers. As the metaphor is said to have originated with Aristotle (Ergin, Sahin, \& Erisen, 2013), it is described as a hidden analogy defining an object with another one based on the power of imagination (Holman, 1980 as cited in Thomas \& Bauchamp, 2011). Metaphor, as a tool of perception (Arnett, 1999), "is the understanding and experiencing of one kind of thing in terms of another" (Lakoff \& Johnson, 1980, p. 5). While Morgan (1998) defines metaphors as a "way of thinking and perceiving" (p. 14), Zhao, Coombs, and Zhou (2010) bring a broad definition to the concept of metaphor and describe it as "metaphors are not just figures of speech, but constitute an essential mechanism of the mind allowing the modeling and reification of prior experience. Thus, metaphors can be understood as a psychological modeling experience leading to new forms of conceptual insight" (p. 381).

In conclusion, in investigating the perceptions, beliefs, and mental conceptions of teachers by using metaphors has proven to be an effective technique in the related literature (e.g., Beijaard, Verloop, \& Vermunt, 2000; Ellis, 1998; Farrell, 2006; Oxford et al., 1998). In this context, it is quite significant to use metaphor analysis in understanding perceptions of teachers about ICT 
through quantitative and qualitative methods, as well as through metaphors, which are considered as highly effective tools in understanding their mental images (Akdemir, Bicer, \& Parmaksiz, 2015). Metaphors, in many aspects, are used to describe complex phenomena (Shaw $\&$ Mahlios, 2011). Therefore, the use of metaphors is seen to be very crucial to explain and understand such complex phenomenon such as ICT. Thus, metaphors in educational contexts play a crucial role in the conceptualization and the reflection of the nature of ICT, and they are also increasingly used to make connections between personal beliefs and educational theories (Leavy, McSorley, \& Boté, 2007). In this regard, metaphors are considered as valuable tools to examine the perceptions of teachers in a deeper context regarding ICT concept. So, in this study, it was tried to detect how ICT is perceived by teachers through metaphors.

\section{Methodology}

\section{Research Design}

In this study, "phenomenological research design", which is one of the qualitative research designs, was adopted to examine teachers' perceptions about ICT (Moustakas, 1994). Phenomenological research aims at gaining an in-depth understanding about the meaning and the nature of everyday experiences (Patton, 2002). A phenomenological study is "to describe the meaning of the lived experience for several individuals about a concept or phenomenon" (Creswell, 1998, p. 51).

\section{Participants}

The study group consisted of 224 volunteering teachers of five different public high schools in Nigde province in the central Anatolia region of Turkey. Unfortunately, a small number of participants did not indicate their demographics. Nevertheless, $43.7 \%(n=98)$ participants were men and $48.2 \%(n=108)$ were women. Anatolian high school teachers $(n=112,50.0 \%)$ constituted the largest group, followed by vocational high school teachers $(n=80,35.7 \%)$ and science high school teachers $(n=23,10.2 \%)$. With regard to occupational experience, $6(2.6 \%)$ teachers had 1-5 years of experience, $83(37.0 \%)$ teachers had 6-10 years of experience, 105 $(46.8 \%)$ teachers had $11-15$ years of experience, and $30(13.3 \%)$ teachers had more than 16 years of occupational experience in the study. Finally, it was seen that the teachers' ages ranged from 25 to 57 years $(M=38, S D=1.72)$ in the study.

\section{Data Collection}

The data of this study were collected from teachers with different branches working in state high schools. While the data of the study were collected by the researcher himself by visiting the schools, the collection of the data lasted for approximately three days. A piece of paper with a prompt on it as "Information and communication technologies are like... because..." was distributed to the teachers. In order to determine the perceptions of teachers about ICT, the teachers were asked to focus solely on a metaphor and complete the given prompt. The teachers were also asked to clarify the reason for choosing their own metaphor. At the same time, the teachers were asked to write some of their demographic information (e.g., gender, occupational experience, educational level) on the paper that was delivered to them. The teachers were given a fifteen-minutes-time to write about a metaphorical image that represented their perceptions 
about ICT. The participants were asked to make ICT resemble to something by using the word like, and give a reason to the metaphorical image they created by using the word because in the research. In this way, the participants were asked to resemble ICT to something, as well as give a reason for it.

\section{Analysis of Data}

The data of the study were analyzed through content analysis technique, which is widely used in qualitative research (Miles \& Huberman, 1994). The main purpose in content analysis is to reach concepts and relationships to explain the collected data (Patton, 2002). Content analysis is a research technique in order to analyze the collected data deeply, and provide new insights, viewpoints, and a representation of facts (Krippendorf, 2013). Content analysis aims at analyzing the data deeply and emerging concepts and themes that could not be discovered through descriptive analysis (Miles \& Huberman, 1994).

The data of the study were tried to be analyzed by following the steps of a metaphor analysis. In this direction, the collected data were tried to be analyzed by following the steps of a metaphor analysis proposed by Saban, Kocbeker, and Saban $(2006,2007)$ in the study. The following steps in analyzing the metaphors in the current research were: (a) naming/labeling, (b) sorting (clarification and elimination), (c) compilation and categorization, (d) establishing the validity and reliability, and (e) analyzing the data quantitatively stages (Saban, Kocbeker, \& Saban, 2006, 2007). The data of the current study were analyzed by following the mentioned procedure above, and the stages in the analysis were given shortly below.

\section{Naming/Labeling Stage}

In this part of the metaphor analysis, a temporary list of all metaphors produced by teachers was created according to the alphabetical order by using MS Word 2007 software. In this step, at the same time, the metaphors which were not supported with a logical rationale were eliminated and were removed from the data set. Some participants were seen to write a metaphor about the topic on the paper, but did not write a logical rationale for this metaphor by using because word (e.g., Information and communication technologies are like chestnut shell, because...). The data which only gave a metaphor but did not give a rationale for it were also removed from the current study. Besides, some metaphors were removed from the data set because they could not be placed under any conceptual category or they were fuzzy and incomprehensible (e.g., Information and communication technologies are like a tree, because we water them everyday).

\section{Sorting (Clarification and Elimination) Stage}

In this part of the metaphor analysis, the raw data were gone through to find similarities or common features with the other metaphors. So, each metaphor was broken down into analyzable parts, and common features amongst these metaphors were looked for. While not every participant produced a logical and rationale metaphor, these metaphors were marked as "poorly-structured" and then were removed from the data set in the study. In this stage, poorlystructured metaphors were removed from the data set based on the following criteria: (a) no metaphor at all, (b) mention about a metaphor but present no provision of a rationale, (c) 
fuzzy/incomprehensible metaphors which do not fit any conceptual category, (d) metaphors which are far off describing the concepts of the research (Saban, Kocbeker, \& Saban, 2007). Finally, a total of 18 pieces of papers were removed from the data set of the study due to the methodological problems they have in conclusion of naming/labeling and sorting (clarification and elimination) stages. After removing the poorly-structured metaphors from the data set, a total of 206 available papers were subjected to compilation and categorization stage.

\section{Compilation and Categorization Stage}

In this step of the study, the raw data were reviewed again, and sample expressions that represented remaining metaphors were chosen. Thus, a metaphor list which was considered to represent the specific metaphors best was formed. In this stage, metaphors produced by the participants about ICT in terms of common characteristics were grouped, and then each metaphor was coded so as to fit into one logical conceptual category. The metaphors produced by the participants were analyzed in regard of (a) the subject of the metaphor, (b) the source of the metaphor, and (c) the relationship between the subject and the source of the metaphor (Saban, 2008). As a result of this inductive analysis, five conceptual categories were reached in terms of ICT concept.

\section{Establishing Validity and Reliability Stage}

First, In order to ensure the validity of the research, the data analysis process was described in detail and the findings were presented without any comment on (Creswell, 1998; Merriam, 1998; Miles \& Huberman, 1994). At the same time, in order to sustain the validity of the data of the study, an expert's opinion was consulted (Merriam, 1998; Patton, 2002), and this expert was asked to examine whether metaphors were grouped under correct conceptual categories or not. Besides, this expert was asked to appoint some of the metaphors into the defined conceptual categories, by this way metaphors were tried to be clarified to fit into those defined conceptual categories. On the other hand, in order to ensure the reliability of the findings of the study, a colleague was asked to match the defined metaphors with the conceptual categories. To estimate the reliability rate of the findings of the study, the interrater reliability formula (Reliability = Agreement $/$ Agreement + Disagreement $x 100$ ) generated by Miles and Huberman (1994) was used. Then, both coders' metaphorical codings were compared with each other and the reliability rate between these two coders was calculated as $99 \%$. In this study, the colleague placed "seed" metaphor under the "knowledge source" conceptual category, however, the researcher considered this metaphor under the "plant" conceptual category. A $90 \%$ or over level of quality between coders or experts in qualitative research is considered as pretty good (Miles \& Huberman, 1994). In conclusion, the desirable reliability rate in the study was acquired. However, although a pretty good reliability rate between the two coders was acquired, an agreement could not be sustained between the two coders in regard of the conceptual category of "seed" metaphor. Hence, the two coders negotiated this metaphor, and finally they reached an agreement so as to conceptualize this metaphor under "plant" category.

\section{Analyzing the Data Quantitatively Stage}

In the last part of the data analysis process, the collected data were registered in SPSS 17.0 software, and frequencies $(f)$ and percentages (\%) of the metaphors produced by the 
participants were calculated. At the same time, metaphors in the conceptual categories produced by the teachers participated in the study were compared by using chi-square analysis technique.

\section{Results}

In this part of the study, metaphors in regard of ICT produced by the teachers were tried to be analyzed. First, the metaphors acquired in the study were presented generally, and then the metaphors in the conceptual categories were tried to be given. Finally, metaphors in terms of ICT produced by the teachers were compared in regard gender variable in the research.

\section{Overall Results}

Teachers participated in the study were seen to produce a total of 46 well-structured metaphors for ICT concept. The top ten dominant metaphors in regard of ICT produced by the teachers were: (1) teacher/educator ( $n=18,8.73 \%),(2)$ north star $(n=15,7.28 \%),(3)$ life $(n=13,6.31 \%)$, (4) Internet $(n=12,5.82 \%)$, (5) computer $(n=10,4.85 \%)$, (6) light $(n=10,4.85 \%)$, (7) revolution ( $n=9,4.36 \%)$, (8) tree $(n=8,3.88 \%)$, (9) tree root $(n=8,3.88 \%)$, (10) Moon ( $n=7,3.39 \%)$. The information in terms of the frequency and percentage distribution of the metaphors produced by the teachers was given in Table 1.

Table 1. Frequency and Percentage Distribution of the Metaphors Regarding Information and Communication Technologies (ICT)

\begin{tabular}{lcc|lcc}
\hline Metaphor & $f$ & $\%$ & Metaphor & $f$ & $\%$ \\
\hline Encyclopedia & 4 & 1.94 & Chaos & 2 & 0.97 \\
Tree & 8 & 3.88 & Book & 6 & 2.91 \\
Tree Root & 1 & 0.48 & North Star & 15 & 7.28 \\
Moon & 7 & 3.39 & Library & 8 & 3.88 \\
Balloon & 1 & 0.48 & Maze & 3 & 1.45 \\
Knowledge Bank & 2 & 0.97 & Leader & 2 & 0.97 \\
Computer & 10 & 4.85 & Mine & 2 & 0.97 \\
Science & 3 & 1.45 & Store & 1 & 0.48 \\
Punishment & 1 & 0.48 & Greengrocer & 1 & 0.48 \\
Exit & 1 & 0.48 & Matryoshka & 1 & 0.48 \\
Flower & 6 & 2.91 & Mine Field & 7 & 3.39 \\
Shepherd & 1 & 0.48 & Candle & 3 & 1.45 \\
Change & 4 & 1.94 & Pomegranate & 2 & 0.97 \\
Lighthouse & 1 & 0.48 & Professor & 1 & 0.48 \\
Revolution & 9 & 4.36 & Compass & 5 & 2.42 \\
Endless Well & 4 & 1.94 & Renaissance & 2 & 0.97 \\
Parent & 1 & 0.48 & Seed & 4 & 1.94 \\
Torch & 4 & 1.94 & Traffic Sign & 3 & 1.45 \\
Sun & 2 & 0.97 & Transistor & 1 & 0.48 \\
Life & 13 & 6.31 & Tour Guide & 1 & 0.48 \\
Light & 10 & 4.85 & Teacher/Educator & 18 & 8.73 \\
Internet & 12 & 5.82 & Innovation & 7 & 3.39 \\
Torture & 5 & 2.42 & Road & 1 & 0.48 \\
\hline
\end{tabular}


When the produced metaphors were taken into account carefully, it was seen that 6 were about human beings (e.g., teacher/educator, shepherd, professor), 5 were about plants (e.g., tree, flower, seed), 25 were about inanimate things/objects (e.g., book, road, matryoshka), and 10 were about abstract things (e.g., revolution, science, punishment)in the study (see Table 1). At the same time, it was understood that 10 metaphors were produced only by female teachers and 8 metaphors were produced only by male teachers. Finally, it was determined that metaphors produced by teachers in regard of ICT were conceptualized under five categories (see Table 2).

Table 2. Categories of the Metaphors Regarding Information and Communication Technologies (ICT)

\begin{tabular}{|c|c|c|}
\hline Category & $\begin{array}{l}\text { Within the } \\
\text { Category } \\
\text {-Participant } n(\%) \\
\text {-Metaphor } n(\%)\end{array}$ & Metaphors Regarding ICT \\
\hline $\begin{array}{l}\text { Knowledge } \\
\text { Source }\end{array}$ & $\begin{array}{l}-66(32.0) \\
-12(26.0)\end{array}$ & $\begin{array}{l}\text { Teacher/Educator (6M, 12F), Professor (1M), Library (5M, 3F), } \\
\text { Book (3M, 3F), Encyclopedia (1M, 3F), Knowledge Bank (1M, 1F), } \\
\text { Transistor (1M), Mine (2F), Internet (8M, 4F), Store (1F), } \\
\text { Greengrocer (1F), Computer (7M, 3F) }\end{array}$ \\
\hline Guide & $\begin{array}{l}-56(27.1) \\
-14(30.4)\end{array}$ & $\begin{array}{l}\text { Compass (3M, 2F), Traffic Sign ( } 2 M, 1 F) \text {, Sun (1M, 1F), North Star } \\
(6 \mathrm{M}, 9 \mathrm{~F}) \text {, Light (3M, 7F), Moon ( } 2 \mathrm{M}, 5 \mathrm{~F}) \text {, Candle (3F), Tour Guide } \\
(1 \mathrm{~F}) \text {, Leader (2M), Lighthouse (1M), Parent (1F), Torch (2M, 2F), } \\
\text { Road (1M), Shepherd (1F) }\end{array}$ \\
\hline Reform & $\begin{array}{l}-26(12.6) \\
-6(13.0) \\
\end{array}$ & $\begin{array}{l}\text { Revolution (5M, 4F), Change (1M, 3F), Innovation (5M, 2F), Exit } \\
(1 \mathrm{~F}) \text {, Renaissance (2F), Science ( } 2 \mathrm{M}, 1 \mathrm{~F})\end{array}$ \\
\hline Plant & $\begin{array}{l}-21(10.2) \\
-5(10.8)\end{array}$ & $\begin{array}{l}\text { Tree }(4 \mathrm{M}, 4 \mathrm{~F}) \text {, Flower }(2 \mathrm{M}, 4 \mathrm{~F}) \text {, Pomegranate }(2 \mathrm{~F}) \text {,Seed }(1 \mathrm{M}, 3 \mathrm{~F}) \text {, } \\
\text { Tree Root }(1 \mathrm{M})\end{array}$ \\
\hline Problem & $\begin{array}{l}-37(17.9) \\
-7(15.2)\end{array}$ & $\begin{array}{l}\text { Life (6M, 7F), Chaos (2F), Mine Field (5M, 2F), Torture (3M, 2F), } \\
\text { Punishment (1M), Endless Well (3M, 1F), Balloon (1F), Maze } \\
\text { (3M), Matryoshka (1F) }\end{array}$ \\
\hline
\end{tabular}

When Table 2 was examined, it was seen that the metaphors produced by the teachers about ICT were grouped under five major categories. The categories acquired in the study were conceptualized as the following; (1) knowledge source, (2) guide, (3) reform, (4) plant, and (5) problem. In this part of the study, the metaphors produced by the teachers were presented generally, and the categories acquired as a means of the metaphor analysis were given in detail under some specific headings.

\section{Conceptual Categories Regarding ICT}

The results for metaphors produced by the teachers for ICT were examined under different conceptual categories below.

\section{Knowledge Source}

The first conceptual category for ICT produced by the teachers participated in the study was "knowledge source". In this category, 66 teachers (\%32.0) produced 12 (\%26.0) well-structured 
metaphors. The following five metaphors were found to be dominant in the study: (1) teacher/educator ( $n=18,8.73 \%)$, (2) Internet ( $n=12,5.82 \%),(3)$ computer $(n=10,4.85 \%),(4)$ library $(n=8,3.88 \%)$, (5) book $(n=6,2.91 \%)$. When the metaphors produced by the teachers were examined in this category, it was understood that the metaphors in this category were mostly things containing a lot of knowledge in them. While, ICT emerged as a knowledge source in this category, it was concluded that teachers perceived ICT in teaching-learning process as a series of tools containing knowledge. From this standpoint, it was determined that the teachers saw ICT equivalent with knowledge, and evaluated it as a source that was to be applied for whenever they needed. This issue can well be seen from the views of the teachers participated in the study below.

Information and communication technologies are like a "teacher" because they have much more knowledge like the teacher.

Information and communication technologies are like the "Internet" because you can reach every kind of information with them.

Information and communication technologies are like a "library" because they contain wide range of information in them.

\section{Guide}

The second conceptual category for ICT produced by the teachers participated in the study was "guide". In this category, 56 teachers (\%27.1) produced 14 (\%30.4) well-structured metaphors. The following five metaphors were found to be dominant in the study: (1) North star ( $n=15$, $7.28 \%)$, (2) light ( $n=10,4.85 \%)$, (3) Moon ( $n=7,3.39 \%)$, (4) compass $(n=5,2.42 \%)$, (5) torch ( $n$ $=4,1.94 \%)$. When the metaphors produced by the teachers were examined in this category, it was understood that the metaphors in this category had the quality of guiding things. While, ICT emerged as a guide in this category, it was concluded that teachers perceived ICT as a guide in teaching-learning process. From this standpoint, it can be said that the teachers considered ICT as a tool for guiding teaching and learning process. This issue can well be seen from the views of the teachers participated in the study below.

Information and communication technologies are like the "North Star" because they guide you to do the right things in instruction.

Information and communication technologies are like the "Moon" because when you lose your way at night, you can find your way via them.

Information and communication technologies are like a "compass" because they always show you the right way, and guide you as well.

\section{Reform}

The other conceptual category for ICT produced by the teachers participated in the study was "reform". In this category, 26 teachers (\%12.6) produced 6 (\%13.0) well-structured metaphors. The following five metaphors were found to be dominant in the study: (1) revolution ( $n=9$, $4.36 \%),(2)$ innovation ( $n=7,3.39 \%)$, (3) change $(n=4,1.94 \%)$, (4) science $(n=3,1.45 \%),(5)$ 
renaissance $(n=2,0.97 \%)$. When the metaphors produced by the teachers were examined in this category, it was understood that the metaphors acquired in this category were mostly things regarding revolution, change, and innovation. While, ICT emerged as a reform act in this category, it was concluded that teachers perceived ICT as a reform act in teaching-learning process. This issue can well be seen from the views of the teachers participated in the study below.

Information and communication technologies are like a "revolution" because when they come, it changes the whole education system radically.

Information and communication technologies are like "innovation" because they bring a change about everything in education.

Information and communication technologies are like the "renaissance" because they rebuild the outdated teaching and learning conception with the new one.

\section{Plant}

Another conceptual category for ICT produced by the teachers participated in the study was "plant". In this category, 21 teachers (\%10.2) produced 5 (\%10.8) well-structured metaphors. The following five metaphors were found to be dominant in the study: (1) tree ( $n=6,2.91 \%)$, (2) flower $(n=6,2.91 \%),(3)$ seed $(n=4,1.94 \%),(4)$ pomegranate $(n=2,0.97 \%),(5)$ tree root $(n=1,0.48 \%)$. When the metaphors produced by the teachers were examined in this category, it was understood that the metaphors in this category were mostly things dealing with the plantation. While, ICT emerged as a plant in this category, it was concluded that teachers perceived ICT in teaching-learning process as a thing that was to be planted, and a thing that penetrated at last. From this standpoint, it was concluded that the teachers saw ICT as a crop, and likened them to a thing that was planted on a field. This issue can well be seen from the views of the teachers participated in the study below.

Information and communication technologies are like a "tree" because the more you plant from them, the more fruit you get.

Information and communication technologies are like a "flower" because one can be fed with them when he/she is teaching like a bee making honey.

Information and communication technologies are like a "seed" because when you plant them once, you get a product a hundred times.

\section{Problem}

The last conceptual category for ICT produced by the teachers participated in the study was "problem". In this category, 37 teachers (\%17.9) produced 9 (\%15.2) well-structured metaphors. The following five metaphors were found to be dominant in the study: (1) life ( $n=13,6.31 \%$ ), (2) mine field ( $n=7,3.39 \%)$, (3) torture $(n=5,2.42 \%)$, (4) maze $(n=3,1.45 \%)$, (5) endless well $(n=4,1.94 \%)$. When the metaphors produced by the teachers were examined in this category, it was understood that the metaphors in this category were mostly problems. While, ICT emerged as a problem in this category, it was concluded that teachers participated in the study 
perceived ICT as an element giving rise to a problem in teaching-learning process. From this standpoint, it can be stated that the teachers considered ICT as a tool that create problems to them in teaching-learning process. This issue can well be seen from the views of the teachers participated in the study below.

Information and communication technologies are like the "life" because they contain many problems in them just like the life itself.

Information and communication technologies are like a "mine field" because they can create problems in every step you take.

Information and communication technologies are like a "maze" because it can be very hard to find your way out when you enter in them.

\section{Impact of Gender Variable on Metaphors}

In this part of the study, the conceptual categories of the metaphors of the teachers about ICT were compared by taking gender variable into account. In order to determine whether metaphors produced by the teachers differ in terms of gender variable, chi-square $\left(\Delta \chi^{2}\right)$ analysis was conducted and the results were presented in Table 3.

Table 3. Distribution of Five Dominant Metaphors by Gender Variable

\begin{tabular}{lllllll}
\hline Conceptual Categories & \multicolumn{2}{c}{$\begin{array}{c}\text { Male } \\
(n=98)\end{array}$} & \multicolumn{2}{c}{$\begin{array}{c}\text { Female } \\
(n=108)\end{array}$} & \multicolumn{2}{c}{$\begin{array}{c}\text { Total } \\
(n=206)\end{array}$} \\
\cline { 2 - 8 } & $f$ & $\%$ & $f$ & $\%$ & $f$ & $\%$ \\
\hline Knowledge Source & 33 & 16.0 & 32 & 15.5 & 66 & 32.0 \\
Guide & 23 & 11.1 & 32 & 15.5 & 56 & 27.1 \\
Reform & 13 & 6.31 & 13 & 6.31 & 26 & 12.6 \\
Plant & 8 & 3.88 & 13 & 6.31 & 21 & 10.2 \\
Problem & 21 & 10.1 & 16 & 7.76 & 37 & 17.9 \\
\hline
\end{tabular}

When Table 3 was examined carefully, it was seen that the metaphors produced by the teachers about ICT did not differ in regard of gender variable in the study $\left(n=206, \Delta \chi^{2}(4)=3.045, p=\right.$ $.550)$. In this sense, it can be concluded that both male and female teachers perceived ICT in the same way. However, a closer look at the percentages showed that female teachers produced more metaphors in "guide" (15.5\%) and "plant" (6.31\%) conceptual categories than their male colleagues ( $11.1 \%$ and $3.88 \%$ respectively). Also, it was seen that male teachers produced more metaphors in "problem" conceptual category than their female colleagues in the study $(10.1 \%$ and $7.76 \%$ respectively).

\section{Discussion}

The purpose of this study was to uncover the metaphors of teachers about information and communication technologies (ICT), and collect these metaphors under certain conceptual categories. These findings acquired in the study draw attention to the following points below. 
First, the teachers participated in the study used many metaphors in order to explain a complex and multidimensional phenomenon such as ICT. While it was seen that teachers produced 46 well-structured metaphors regarding ICT, these metaphors were understood to be grouped under five conceptual categories. The metaphors generated by the teachers were conceptualized under the following categories; (1) knowledge source, (2) guide, (3) reform, (3) plant, and (5) problem. In these categories, it was seen that the most common metaphors were produced in the context "guide" ( $n=14,30.4 \%)$ and "knowledge source" ( $n=12,26.0 \%)$ categories. The other dominant conceptual categories were "problem" $(n=7,15.2 \%)$, "reform" $(n=6,13.0 \%)$, and "plant" $(n=5,10.8 \%)$, respectively.

There are two elements in these produced metaphors that attract attention. The first of these is that teachers have negative perceptions about ICT, and the second one is that teachers perceive ICT as a reform. These two concepts can be evaluated essentially as contrasted to each other. In this regard, it can be said that while the teachers consider ICT as a reform in the education system, they see it as a problem as well. While the teachers see ICT as a tool of change, transformation, and innovation under reform conceptual category, they see it as dangerous, chaotic, and a tool of punishment inflicting torture to people under problem conceptual category as well. The relevant literature also supports that metaphors produced upon such concepts as computer, Internet, and technology are perceived as problem and/or change (e.g., Akdemir, Bicer, \& Parmaksiz, 2015; Coklar \& Bagci, 2010; Erdogan \& Gok, 2008; Gurol \& Donmus, 2010; Karadeniz, 2012; Koc, 2013). Overall, it can be said that the teachers have positive perceptions about ICT. On the other hand, when the metaphors produced by the teachers participated in the study in regard of conceptual categories were evaluated in a general sense, it was understood that the teachers considered ICT as a knowledge source and perceive it as having the quality of a guide in teaching and learning process.

These findings can be explained by teaching-learning conceptions of teachers in the TES (Bas, 2014). Despite the MoNE of Turkey tries hard to develop the curricula in the light of the constructivist approach for the past ten years, it is seen that teaching-learning conceptions of teachers are observed to be not in this direction. Although it is seen that teachers adopt constructivist teaching-learning conception (Aypay, 2011; Bas, 2014), they still continue to apply traditional teaching-learning conception in education (see Yilmaz \& Altinkurt, 2011); meaning that they have philosophy of education beliefs parallel to their teaching-learning conceptions (Bas, 2015). Therefore, it is concluded that teachers' teaching-learning conceptions and their philosophy of education beliefs may be reflected on the metaphors they use about ICT. When the related literature is reviewed, it is seen that there are some similar studies about metaphor analysis regarding such concepts as educational technology, computer, Internet, and technology (e.g., Erdogan \& Gok, 2008; Gecer, 2013; Gok \& Erdogan, 2010; Gurol \& Donmus, 2010; Kobak \& Taskin, 2012; Karadeniz, 2012; Koc, 2013). In many of these studies, it is seen that teachers or teacher candidates consider such concepts as educational technology, computer, Internet, and technology mostly as a knowledge source, and associate these concepts, in a manner similar to the finding of the current study, with library, book, encyclopedia, teacher metaphors. Ultimately, each of these metaphors is a source of knowledge and they reflect the viewpoints of teachers or teacher candidates regarding computer, Internet, and technology.

On the other hand, the first ten dominant metaphors about ICT produced by the teachers participated in the study constituted the following; (1) teacher/educator ( $n=18,8.73 \%),(2)$ North star ( $n=15,7.28 \%),(3)$ life $(n=13,6.31 \%)$, (4) Internet $(n=12,5.82 \%)$, (5) computer $(n$ $=10,4.85 \%)$, (6) light $(n=10,4.85 \%)$, (7) revolution ( $n=9,4.36 \%),(8)$ tree $(n=8,3.88 \%),(9)$ tree root $(n=8,3.88 \%),(10)$ Moon $(n=7,3.39 \%)$. As the first ten metaphors are evaluated, it is 
seen that most of the metaphors produced were grouped under "knowledge source" and "guide" categories, which are the most dominant conceptual categories in the study. Hence, it can be said that the relevant research literature (e.g., Erdogan \& Gok, 2008; Gilbert \& Kelly, 2005; Gok \& Erdogan, 2010; Karadeniz, 2012) mostly supports the findings acquired in the current study. At the same time, as the metaphors produced in the study were taken into account in general, it was seen that 6 of these metaphors were about human beings (e.g., teacher/educator, shepherd, professor), 5 of the these metaphors were about plantation (e.g., tree, flower, seed), 25 of these metaphors were about inanimate things/objects (e.g., book, road, matryoshka), and 10 of them were about abstract things (e.g., revolution, science, punishment). In many studies, it was determined that metaphors produced by teachers and teacher candidates regarding educational technology, computer, Internet, and technology were conceptualized under human characteristics, inanimate things/objects, and abstract things (e.g., Erdogan \& Gok, 2008; Gilbert \& Kelly, 2005; Gok \& Erdogan, 2010; Karadeniz, 2012; Koc, 2013).

In addition, it was understood that 10 metaphors were produced only by female teachers and 8 metaphors were generated only by male teachers in the study. Also, it was seen that the metaphors of the teachers about ICT did not differ significantly in terms of gender variable. Accordingly, it was revealed that both male and female teachers perceived ICT in the same way. The research literature reports that gender variable, in general, has no significant effect on the metaphors generated by teachers or teacher candidates (e.g., Gurol \& Donmus, 2010; Karadeniz, 2012; Koc, 2013). In this study, while it was also seen that gender variable has no significant effect on the metaphors generated by the teachers about ICT, the acquired findings can be said to support the research literature.

This study has significant results in regard of the integration of ICT into teaching and learning process by teachers in many aspects. First, previous research was seen to focus on metaphorical perceptions of teachers and teacher candidates about educational technology, computer, Internet, and technology. In this study, unlike the others, teachers' metaphorical perceptions directly about the nature of ICT were tried to be examined. Of course, metaphorical perceptions of teachers or teacher candidates about such concepts as computer, Internet and technology are very important; however, they can be said to be far from putting forth the perceptions about ICT exactly because these concepts only represent the components of ICT, not the whole of it. Therefore, this study can be stated to be quite important for putting forth on how teachers perceive ICT in general. Because such a determination of the perceptions of teachers about ICT is critically important to put forth in what level they adopt and use ICT in teaching and learning process. This situation may provide significant clues in uncovering the level of teachers' integration of ICT in teaching and learning process in the classroom.

The findings of the study indicate that teachers consider ICT as knowledge source and believe it as a tool for guiding them in teaching and learning process. The findings reveal that teachers cannot use ICT effectively, and use it only as a way of getting information in teaching and learning process. The findings, at the same time, demonstrate that teachers believe in ICT as a tool for guiding them just as the teacher guide books that they use. Whereas, ICT is not required to direct teachers in teaching and learning process, however, teachers are required to direct ICT in teaching and learning process in the classroom. On the other hand, the findings acquired in the study also show that teachers perceive ICT both as a reform and as a problem. Even though few teachers were seen to perceive ICT as a reform, this is considered very important to note in this research. Because, there are such findings in the literature that ICT applications change the social and economic development of countries seriously (Kozma, 2011), provide significant contributions to countries in being an information society (OECD, 1999), and improve teaching 
and learning process in the classroom (Higgins, 2003). Furthermore, it was concluded in the study that teachers perceived ICT as a problem, as well. While the research literature reports that teachers or teacher candidates perceive ICT as a problem (e.g., Gurol \& Donmus, 2010; Kobak \& Taskin, 2012; Koc, 2013; Kucuk \& Yalcin, 2014), there may be many reasons underlying their perceptions (Bingimlas, 2009; Pelgrum, 2001). In particular, negative level of teacher selfefficacy, computer self-efficacy perception and attitude towards computer (Sang, Valcke, van Braak, \&Tondeur, 2010), ICT self-efficacy (Goktas, Yildirim, \& Yildirim, 2009), and low level of technological pedagogical content knowledge (TPACK) self-efficacy (Chai, Koh, Tsai, \& Tan, 2011) may have been effective in putting forward negative metaphors about ICT by teachers.

This study is believed to have some vital implications regarding ICT-based F@tih project, implemented by the MoNE. Indeed, the findings acquired in the study are thought to be quite significant in the effective integration of ICT in the TES. The findings from the study indicated that most of the teachers did not have the right perceptions in regard of the real function of ICT. In the findings of the study, while it was determined teachers see ICT mostly as knowledge source, they believed that it had a function of guiding them, and considered it as a problem. Although it was seen that a minority group of teachers perceived ICT as a reform, which is considered as quite important, teachers were understood not to generate enough metaphors in terms of the meaning of ICT in teaching and learning process. In this sense, the MoNE should take necessary steps to make teachers integrate ICT in teaching and learning process efficiently, as well as it is seen crucial that it should subject teachers to both theoretical and practical inservice training at this point because the relevant research literature also reports that teachers do not have enough in-service training in terms of ICT (Goktas, Gedik, \& Baydas, 2013; Ozdemir $\&$ Kilic, 2007). At the same time, it is quite significant that teachers are subjected to practical inservice training by the MoNE in order to integrate ICT within curriculum. Besides, supporting teaching and learning process solely with hardware and software may not guarantee an effective ICT integration (Somyurek, Atasoy, \& Ozdemir, 2009). It is that teachers, who are the leading actors in the effective integration of ICT in teaching and learning environment should never be forgotten (Goktas, Yildirim, \& Yildirim, 2008; Smeets, 2005), and they should be taken into necessary training for an effective ICT integration (Mims, Polly, Shepherd, \& Inan, 2006).

Finally, it can be said that the metaphor analysis applied in the current study is promising for the future studies. Indeed, it is seen that many studies examining the perceptions of teachers or teacher candidates about ICT have been carried out by considering quantitative data collection tools. Unlike the data collection tools which try to measure the perceptions of teachers through predetermined items, and in this sense put an obstacle to make teachers express their free opinions and beliefs, a prompt which allowed teachers to write their own opinions or perceptions easily and freely was used in this study. In this way, teachers were asked to draw inferences about the nature of ICT by producing sorts of thoughts they wished in the research.

\section{Implications for Practice}

The current study has some implications for educational practice. According to the findings, the teachers participated in the research perceived ICT as knowledge source, guide, reform, plant, and problem. The findings imply that teachers consider ICT a source where they get information and a guide which directs them in teaching-learning process. Also, the findings indicate that teachers perceive ICT as a reform act as well as a problem. Therefore, the findings suggest that teachers should be sustained to direct teaching-learning process in a constructivist way, unlike using ICT as a knowledge source. Hence, appropriate educational settings should be sustained 
to teachers to implement an active teaching-learning process by using ICT. Also, the findings indicate that teachers should be made benefit more from the necessary platforms of ICT, such as the Education and Information Web (EIW) (see www.eba.gov.tr) since they consider ICT as a guide. Therefore, the content in the EIW should be broadened both in quality and quantity. On the other hand, the findings also suggest that teachers' negative perceptions towards ICT should be understood and necessary precautions should be taken. Since the teachers participated in the research perceive ICT as a problem, it is considered that negative perceptions of teachers can enable the integration of ICT into teaching and learning. Therefore, the underlying reasons should be well documented, and teachers should be supported in the use of ICT in the classroom.

\section{Conclusions}

The current research examined the metaphors produced by teachers about ICT. The research findings showed that a total of 46 well-structured metaphors for ICT concept was produced by teachers. The top ten dominant metaphors in regard of ICT produced by the teachers were: teacher/educator, North Star, life, Internet, computer, light, revolution, tree, tree root, and Moon. Also, it was seen that the metaphors produced by the teachers about ICT were grouped under five categories. The categories acquired in the study were conceptualized as the following;

knowledge source, guide, reform, plant, and problem. Finally, it was not found any significant difference between teachers' metaphorical conceptions about ICT with regard to gender variable.

\section{References}

Akdemir, O., Bicer, D., \& Parmaksiz, R. S. (2015). Prospective teachers' information and communication technology metaphors. World Journal on Educational Technology, 7(1), 9-21.

Alpaslan, S. (2007). A comparison of metaphors of management in industry and information societies (Unpublished master's thesis). Sakarya University, Turkey.

Altun, T. (2002). Factors influencing teachers' change in classroom practice due to introduction of information and communications technology (ICT) in Turkey (Unpublished doctoral dissertation). University of Nottingham, Nottingham, UK.

Arnett, R. C. (1999). Metaphorical guidance: Administration as building and renovation. Journal of Educational Administration, 37(1), 80-89.

Aypay, A. (2011). The adaptation of the teaching-learning conceptions questionnaire and its relationships with epistemological beliefs. Educational Sciences: Theory \& Practice, 11(1), 21-29.

Bas, G. (2015). Correlation between teachers' philosophy of education beliefs and their teaching-learning conceptions. Education and Science, 40(182), 111-126.

Bas, G. (2014). Ilkogretim ogretmenlerinin ogretme-ogrenme anlayislarinin bazi degiskenler acisindan degerlendirilmesi [Evaluation of elementary school teachers' teaching-learning conceptions in terms of different variables]. Dicle Universitesi Ziya Gokalp Egitim Fakultesi Dergisi, 22, 18-30. 
Beijaard, D., Verloop, N., \& Vermunt, J. D. (2000). Teachers' perceptions of professional identity: An exploratory study from a personal knowledge perspective. Teaching and Teacher Education, 16, 749-764.

Bingimlas, K. A. (2009). Barriers to the successful integration of ICT in teaching and learning environments: A review of the literature. Eurasia Journal of Mathematics, Science \&Technology Education, 5(3), 235-245.

Blurton, C. (1999). New directions in ICT-use in education. Paris: UNESCO.

Borich, G. D. (2014). Effective teaching methods: Research-based practice (8th ed.). Boston, MA: Pearson.

Chai, C. S., Koh, J. H. L., Tsai, C. C., \& Tan, L. L. W. (2011). Modeling primary school pre-service teachers' technological pedagogical content knowledge (TPACK) for meaningful learning with information and communication technology (ICT). Computers \& Education, 57(1), 1184-1193.

Ciftci, S., Taskaya, S. M., \& Alemdar, M. (2013). The opinions of classroom teachers about FATIH project. Elementary Education Online, 12(1), 227-240.

Creswell, J. W. (1998) Qualitative inquiry and research design: Choosing among five traditions. Thousand Oaks, CA: Sage.

Coklar, A. N. \& Bagci, H. (2010). What are the roles of prospective teachers on the educational technology use: A metaphor study. World Journal on Educational Technology, 2(3), 186195.

Davies, J. \& Brember, I. (2001). The closing gap in attitudes between boys and girls: A 5-year longitudinal study. Educational Psychology, 21(1), 103-114.

Dundar, H. \& Akcayir, M. (2014). Implementing tablet PCs in schools: Students' attitudes and opinions. Computers in Human Behavior, 32, 40-46.

Ellis, R. (1998). The metaphorical constructions of second language learners. Paper presented at the American Association for Applied Linguistics Conference. Seattle, WA.

Erdogan, T. \& Gok, B. (2008). An examination of primary school teacher candidates' perceptions about technology through metaphor analysis. Paper presented at the 8th International Educational Technology Conference. Eskisehir, Turkey.

Ergin, B., Sahin, M., \& Erisen, Y. (2013). Prospective pre-school teachers' perceptions of "child": A study of metaphors. International Journal on New Trends in Education and Their Implications, 4(4), 88-101.

Farrell, T. S. C. (2006). 'The teacher is an octopus': Uncovering preservice English language teachers' prior beliefs through metaphor analysis. Regional Language Centre Journal, $37(2), 236-248$.

Fraenkel, J. R. \& Norman E. W. (2009). How to design and evaluate research in education (8th ed.). New York: McGraw-Hill.

Gecer, A. (2013). Determination of the computer self-efficacy perception of students and metaphors noted to computer ownership. The Turkish Online Journal of Educational Technology, 12(3), 51-71.

Gilbert, J. \& Kelly, R. (2005). Frontiers and frontlines: Metaphors describing lecturers' attitudes to ICT adoption. Educational Technology \& Society, 8(3), 110-121. 
Gok, B. \& Erdogan, T. (2010). Investigation of pre-service teachers' perception about concept of technology trough metaphor analysis. The Turkish Online Journal of Educational Technology, 9(2), 145-160.

Goktas, Y., Gedik, N., \& Baydas, O. (2013). Enablers and barriers to the use of ICT in primary schools in Turkey: A comparative study of 2005-2011. Computers \& Education, 68, 211222.

Goktas, Y., Yildirim, Z., \& Yildirim, S. (2009). Investigation of K-12 teachers' ICT competencies and the contributing factors in acquiring these competencies. The New Educational Review, 17(1), 276-294.

Goktas, Y., Yildirim, Z., \& Yildirim, S. (2008). The keys for ICT integration in K-12 education: Teachers' perceptions and usage. Hacettepe Universitesi Egitim Fakultesi Dergisi, 34,127-139.

Gurol, M. \& Donmus, V. (2010). Metaphors created by prospective teachers related to the concept of "social network". Procedia-Social and Behavioral Sciences, 9, 1489-1496.

Higgins, S. J. (2003). Does ICT improve learning and teaching in schools? Southwell: British Educational Research Association.

Huang, H. M. \& Liaw, S. S. (2005). Exploring users' attitudes and intentions toward the web as a survey tool. Computers in Human Behavior, 21(5), 729-743.

Inan, F. A. \& Lowther, D. L. (2010). Factors affecting technology integration in K-12 classrooms: A path model. Educational Technology Research and Development, 58(2), 137-154.

Karadeniz, S. (2012). School administrators, ICT coordinators and teachers' metaphorical conceptualizations of technology. Education, 2(5), 101-111.

Kalra, M. B. \& Baveja, B. (2012). Teacher thinking about knowledge, learning and learners: A metaphor analysis. Procedia-Social and Behavioral Sciences, 55, 317-326.

Kauchak, D. \& Eggen, P. (2012). Learning and teaching: Research-based methods (6th ed.). Boston, MA: Pearson.

Kobak, M., \& Taskin, N. R. (2012). Prospective teachers' perceptions of using technology in three different ways. Procedia-Social and Behavioral Sciences, 46, 3629-3636.

Koc, M. (2013). Student teachers' conceptions of technology: A metaphor analysis. Computers \& Education, 68, 1-8.

Kozma, R. B. (2011). The potential of ICT to support education change. Transforming Education: The Power of ICT policies (pp. 19-34). Paris: UNESCO.

Krippendorf, K. (2013). Content analysis: An introduction to its methodology (3rd ed.). Thousand Oaks, CA: Sage.

Kucuk, M. \& Yalcin, Y. (2014). Turkish elementary school teacher candidates' technology metaphors. Turkish Journal of Teacher Education, 3(1), 53-63.

Kurt, A. A., Kuzu, A., Dursun, O. O., Gullepinar, F., \& Gultekin, M. (2013). Evaluation of the pilot application process of the FATIH Project: Teacher views. Journal of Instructional Technologies \& Teacher Education, 2(1), 1-23.

Lai, K. W. \& Pratt, K. (2004). Information and communication technology (ICT) in secondary schools: The role of the computer coordinator. British Journal of Educational Technology, 35(4), 461-475. 
Lakoff, G. \& Johnson, M. (1980). Metaphors we live by. Chicago, IL: University of Chicago Press.

Leavy, A. M., McSorley, F. A., \& Boté, L. A. (2007). An examination of what metaphor construction reveals about the evolution of pre-service teachers' beliefs about teaching and learning. Teaching and Teacher Education, 23, 1217-1233.

Light, D. (2009). The role of ICT in enhancing education in developing countries: Findings from an evaluation of the Intel ${ }^{\circledast}$ teach Essentials course in India, Turkey, and Chile. Journal of Education for International Development, 4(2), 52-66.

Livingstone, S. (2012). Critical reflections on the benefits of ICT in education. Oxford Review of Education, 38(1), 9-24.

Loveless, A. M. (2003). The interaction between primary teachers' perceptions of ICT and their pedagogy. Education and Information Technologies, 8(4), 313-326.

Marvin, C. (1997). When old technologies were new. Oxford: Oxford University Press.

Merriam, S. B. (1998). Qualitative research and case study applications in education. San Francisco: Jossey-Bass.

Miles, M. B. \& Huberman, A. M. (1994). Qualitative data analysis: An expanded sourcebook (2nd ed.). Thousand Oaks, CA: Sage.

Mims, C., Polly, D., Shepherd, C., \& Inan, F. (2006). Examining PT3 projects designed to improve preservice education. TechTrends, 50(3), 16-24.

Morgan, G. (1998). Metaphor in management and organisation theories. Istanbul: MESS.

Moustakas, C. (1994). Phenomenological research methods. Thousand Oaks, CA: Sage.

OECD (1999). Knowledge management in the learning society. Paris: OECD/CERI.

Oxford, R. L., Tomlinson, S., Barcelos, A., Harrington, C., Lavine, R. Z., \& Saleh, A. (1998). Clashing metaphors about classroom teachers: Toward a systematic typology for the language teaching field. System, 26, 3-50.

Ozdemir, S. \& Kilic, E. (2007). Integrating information and communication technologies in the Turkish primary school system. British Journal of Educational Technology, 38(5), 907916.

Papanastasiou, E. C. \& Angeli, C. (2008). Evaluating the use of ICT in education: Psychometric properties of the survey of factors affecting teachers teaching with technology (SFA-T3). Educational Technology \& Society, 11(1), 69-86.

Patton, M. Q. (2002). Qualitative research and evaluation methods (3rd ed.). Thousand Oaks, CA: Sage.

Pelgrum, W. J. (2001). Obstacles to the integration of ICT in education: Results from a worldwide educational assessment. Computers \& Education, 37(2), 163-178.

Saban, A. (2008). Okula iliskin metaforlar [Metaphors in relation to school]. Kuram ve Uygulamada Egitim Yonetimi, 55(55), 459-496.

Saban, A., Kocbeker, B. N., \& Saban, A. (2007). Prospective teachers' conceptions of teaching and learning revealed through metaphor analysis. Learning and Instruction, 17, 123-139.

Saban, A., Kocbeker, B. N., \& Saban, A. (2006). An investigation of the concept of teacher among prospective teachers through metaphor analysis. Educational Sciences: Theory \& Practice, 6(2), 509-522. 
Sang, G., Valcke, M., van Braak, J., \& Tondeur, J. (2010). Student teachers' thinking processes and ICT integration: Predictors of prospective teaching behaviors with educational technology. Computers \& Education, 54(1), 103-112.

Selwyn, N. (2004). Reconsidering political and popular understandings of the digital divide. New Media \& Society, 6(3), 341-362.

Shaw, D. M., \& Mahlios, M. (2011). Literacy metaphors of pre-service teachers: Do they change after instruction? Which metaphors are stable? How do they connect to theories? Journal of Education for Teaching, 37(1), 77-92.

Smeets, E. (2005). Does ICT contribute to powerful learning environments in primary education? Computers \& Education, 44(3), 343-355.

Somyurek, S., Atasoy, B., \& Ozdemir, S. (2009). Board's IQ: What makes a board smart? Computers \& Education, 53(2), 368-374.

Teo, T. (2008). Pre-service teachers' attitudes towards computer use: A Singapore survey. Australasian Journal of Educational Technology, 24(4), 413-424.

Tezci, E. (2010). Attitudes and knowledge level of teachers in ICT use: The case of Turkish teachers. International Journal of Human Sciences, 7(2), 19-44.

Thomas, L. \& Bauchamp, C. (2011). Understanding new teachers' professional identities through metaphor. Teaching and Teacher Education, 27(4), 762-769.

Tondeur, J., Valcke, M., \& van Braak, J. (2008). A multi dimensional approach to determinants of computer use in primary education: Teacher and school characteristics. Journal of Computer Assisted Learning, 24(6), 494-506.

Tondeur, J., van Keer, H., van Braak, J., \& Valcke, M. (2008). ICT integration in the classroom: Challenging the potential of a school policy. Computers \& Education, 51(1), 212-223.

Uluyol, C. (2013). ICT integration in Turkish schools: Recall where you are coming from to recognize where you are going to. British Journal of Educational Technology, 44(1), E10E13.

Watson, D. M. (2001). Pedagogy before technology: Re-thinking the relationship between ICT and teaching. Education and Information technologies, 6(4), 251-266.

Wilson, D. N. (2003). The future of comparative and international education in a globalised world. International Review of Education, 49(1-2), 15-33.

Yilmaz, M. B. (2011). Opinions of primary school teachers on their students' ICT skills and information technologies course. Procedia-Social and Behavioral Sciences, 28, 503-509.

Yilmaz, K. \& Altinkurt, Y. (2011). Views of prospective teachers about the problems of the Turkish education system. International Journal of Human Sciences, 8(1), 942-973.

Zhao, H., Coombs, S., \& Zhou, X. (2010). Developing professional knowledge about teachers through metaphor research: facilitating a process of change. Teacher Development, 14(3), 381-395.

Correspondence: Gokhan Bas, Assistant Professor, Department of Curriculum and Instruction, College of Education, Nigde Omer Halisdemir University, Nigde, Turkey. 